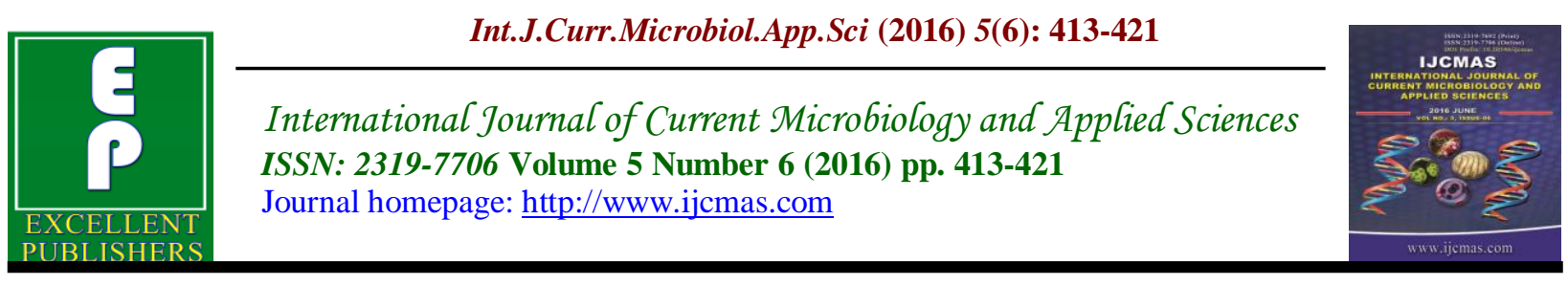

Original Research Article

http://dx.doi.org/10.20546/ijcmas.2016.506.048

\title{
Evaluation of the Effectiveness of Live Synergistic Bacteria as a Bioremediation agent for selected Heavy Metals in Soils in Apapa-Lagos
}

\author{
G.I. Oyet and P. Audu* \\ ${ }^{1}$ Environment, Health, Safety and Quality department, Oando marketing Plc, Apapa, \\ Lagos state, Nigeria \\ ${ }^{2}$ Environment, Health, Safety and Quality department, Oando marketing Plc, \\ Onne Terminal, Rivers state, Nigeria \\ *Corresponding author
}

\begin{abstract}
A B S T R A C T
Keywords

Bio-remediation, live synergistic bacteria, heavy metal, soil, contamination, sampling, analysis.

\section{Article Info}

Accepted:

20 May 2016

Available Online:

10 June 2016

The effectiveness of live synergistic bacteria as a bio-remediation agent for heavy metals such as arsenic, barium, cadmium, chromium, cobalt, copper, mercury, lead, nickel and zinc in soils in apapalagos was evaluated. Soil samples were taken from impacted stations and analysed for physicochemical parameters and heavy metals selected. Diluted live synergistic bacteria was applied on the site and a lag period was allowed. After the lag period, post application soil samples were again taken from the established sampling station and analysed for the selected parameters. Sampling and analysis were in accordance with standard procedures. The results show that live synergistic bacteria was able to adjust the soil $\mathrm{pH}$, the electrical conductivity and total organic content but was not effective in adjusting heavy the metals for which it was tested within the limits of experimental errors.
\end{abstract}

\section{Introduction}

The high industrialization in Lagos state, Nigeria has made it one of the most heavily populated constituency on the earth. Lagos state was estimated to have a population of about 9.3millions in 2006, (NPC, 2006). The Lagos State Government estimates the population of Lagos at 17.5 million, although this number has been disputed by the Nigerian Government and found to be unreliable by the National Population Commission of Nigeria, which put the population at about 21 million in 2014 . More than $50 \%$ of Nigeria's industrial activities including 300 industries in 12 industrial Estates are located in the Lagos area. The continuous increase in population and industrial growth in Lagos persistently cause large volume of waste to be generated (about 10,000 tons per day) (Oresanya, 2000) and environmentally safe landfills to cater for these wastes were inadequate. However, with the introduction of integrated 
solid waste management system (ISWMS) initiated by the Lagos state waste management authority (LAWMA), there is significant reduction in the quantity of waste to be landfilled.

Apapa is one of the areas housing the industrial estates in Lagos including petroleum products tank farms and terminals. Soils in these areas are heavily contaminated as a result of the activities of these industries.

Usually, soils are considered as a sink for trace metals. Then, trace metals are able to move towards the water column or accumulate in plants and consequently contaminate the food chain (Odukoya et al., 2011). Of major concern about the presence of some metal ions in the environment are the negative health effects that they may cause in humans, animals, and plants (Mohammad and Nerges, 2009; Odukoya and Abimbola, 2010). Metal distribution depends on the characteristics of the soils being studied and corresponds to the place of origin, such as the amount and type of organic and inorganic matter. Redox properties, $\mathrm{pH}$ and oxygen are among the most important chemical factors that affect the mobility of soil-bound metals [Duris, 2002; Guo and Zhou, 2006; Pandey et al., 2006 and Winfield, 2001].

Anthropogenic sources of metal contamination include smelting of metalliferous ore, electroplating, gas exhaust, energy and fuel production, application of fertilizers and municipal sludges to land and industrial manufacturing (Blaylock and Huang, 2000; Vasiliadou and Dordas, 2009, Keet al., 2001,

Studies of metal concentrations in soil ingested by people via the hand to mouth pathway have also been carried out in a number of places according to Watt et al., 1993; Higgs et al., 1997. There is substantial evidence that a high Lead level in an environment could affect blood Lead level, intelligence and behavior (Bellinger et al., 1990; Lanphear et al., 1998). It is especially important that soil contents of potentially harmful substances are kept low in areas frequented by humans. Other metals such as $\mathrm{Cd}, \mathrm{Cu}, \mathrm{Pd}$ and $\mathrm{Zn}$ are good indicators of contamination in soils because they appear in gasoline, car component, oil lubricants and industrial incinerator emissions (Popoola et al., 2012). Trace amount of some metals such as trivalent chromium and cadmium entering the body via various routes can induce genetic and epigenetic alteration in different cancer related genes of somatic and stem cells, thus involving in cancer stem cell formation and increasing the incidence of cancer (Popoola et al., 2012).

Bioremediation is a waste management technique that involves the use of organisms to remove or neutralize pollutants from a contaminated site (NRC, 1993). Microorganisms are ideally suited to the task of contaminant destruction because they possess enzymes that allow them to use environmental contaminants as food and because they are so small that they are able to contact contaminants easily.

Whether microorganisms will be successful in destroying man-made contaminants in the subsurface depends on three factors: the type of organisms, the type of contaminant, and the geological and chemical conditions at the contaminated site (NRC, 1993). The goal in bioremediation is to stimulate microorganisms with nutrients and other chemicals that will enable them to destroy the contaminants. Although bioremediation currently is used commercially to cleanup a limited range of contaminants-mostly 
hydrocarbons found in gasolinemicroorganisms have the capability to biodegrade almost all organic contaminants and many inorganic contaminants.

This work is to assess the effectiveness of a bioremediation agent - live synergistic bacteria, against selected heavy metals such as arsenic, barium, cobalt, cadmium, chromium, lead, copper, nickel and zinc in soils.

\section{Experimental}

Soil samples were collected using hand trowel to the depth of contamination $(0.5 \mathrm{~m})$. Composite samples were obtained from four spots at each visible impacted site and homogenized. The samples were taken for physico-chemical and heavy metals analysis in aluminium foil plates and stored in accordance with the provisions in the Environmental Guidelines And Standards for Petroleum Industry in Nigeria(EGASPIN, 2002) on the field before onward delivery to the laboratory (USEPA, 2000).

Soil with visible impacts (sheen, staining etc) were sampled and segmented into point 1 , point 2 , point 3 and point 4 as indicated in figure1.1.

Point 1 is approximately $4.97 \mathrm{~m} \times 4.0 \mathrm{~m}=$ $19.88 \mathrm{~m} 2$

Point 2 is approximately $1.74 \mathrm{~m} \times 4.0 \mathrm{~m}=$ $6.96 \mathrm{~m} 2$

Point 3 is approximately $2.35 \mathrm{~m} \times 4.0 \mathrm{~m}=$ $9.40 \mathrm{~m} 2$

Point 4 is approximately $10.28 \mathrm{~m} \times 4.0 \mathrm{~m}=$ $41.12 \mathrm{~m} 2$

Laboratory analysis of the collected samples was guided by the statutory provisions in FMENV/DPR guidelines. The methodology for laboratory analyses was consistent with relevant established procedures (APHA,
ASTM). Description of the methodology are presented below. Search gate laboratories limited, a government approved laboratory, was engaged for the analyses of the sample. The results of the analyses were recorded.

$10 \%$ by volume of concentrated live synergistic bacteria was prepared using potable water. 230 litres of the $10 \%$ by volume of the live synergistic bacteria was applied to the selected impacted soil with the use of a watering can. The application took 10 hours to cover the area effectively. The area of the soil where the agent was applied was left and secured for 3 days to avoid further activities that could impact on the soil which could consequently weaken the effectiveness of the agent.

Another set of soil samples were taken from the four established sampling stations as "post remedial-agent application samples" using the same procedures. The second samples were analyzed for the previously indicated parameters and the results were recorded.

\section{Results and Discussion}

The results of analyses conducted on the pre-application soil samples and those of the post application soil samples at the respective segmented points 1 to 4 are as shown in table 2.1.

From Table 2.1, the $\mathrm{Ph}$ values ranged from 5.1 to 5.8 during pre-application sampling while the $\mathrm{pH}$ values ranged from 5.7 to 6.1 during the post-application sampling. This indicates reduction in the acidity of the soil. Valuesbetween5and9suggestoptimalreductiv epathwayconditions.Songetal.(1990)reported similarresults with $\mathrm{pH}$ in a polluted soil after a bioremediation experiment. These behavior is represented in figure 2.1 
Conductivity ranged from $26.9 \mu \mathrm{S} / \mathrm{cm}$ to $214.4 \mu \mathrm{S} / \mathrm{cm}$ during pre-application sampling while the value ranged from 27.3 $\mu \mathrm{S} / \mathrm{cm}$ to $210.8 \mu \mathrm{S} / \mathrm{cm}$ after the lag phase. Values indicate anaerobic degradation trend. The behavior of conductivity in both the preapplication and post application sample is represented in a bar chart in figure 2.2.

Total organic content (TOC) ranged from 0.92 to $2.10 \%$ during the pre-application sampling while the value ranged from 0.73 to $1.90 \%$ after the lag phase. The result indicates that TOC has reduced. This suggest that biodegradation is likely occurring (Bragg et al., 1994; Venosa et al., 1996). As described in other studies, the degradation pattern of organic chemicals in soil usually shows a rapid initial phase of descent followed by a period of little or no change in concentration. This kinetics is known as the "hockey stick" phenomenon (Alexander, 1999). The change of impacted soil total organic content is as shown in figure 2.3.

For heavy metals such as arsenic, barium, cadmium chromium, cobalt, copper, mercury, lead, nickel and zinc, the results are somewhat erratic. However, the general trend which is disenable shows that the agent was not effective in remediation against these metals. Barium, cadmium, chromium, cobalt, copper, lead, nickel and zinc were present in the samples. Lead recorded the highest concentration of $92.388 \mathrm{mg} / \mathrm{kg}$ at pre-application point 4 and $83.052 \mathrm{mg} / \mathrm{kg}$ at post application point 2 .

Table.1 Soil samples handling and preservation procedure

\begin{tabular}{|l|l|l|l|}
\hline Parameters & Containers & Preservative & $\begin{array}{l}\text { Container pre- } \\
\text { treatment }\end{array}$ \\
\hline $\begin{array}{l}\text { Metals: } \mathrm{Ar}, \mathrm{Ba}, \mathrm{Cd}, \\
\mathrm{Cr}, \mathrm{Co}, \mathrm{Cu}, \mathrm{Hg}, \mathrm{Pb}, \\
\mathrm{Ni}, \mathrm{Zn}\end{array}$ & Plastic bag & Freeze & $\begin{array}{l}\text { Rinse with distilled } \\
\text { water }\end{array}$ \\
\hline $\begin{array}{l}\text { Physico-chemical: } \\
\text { TOC, } \mathrm{pH},\end{array}$ & Plastic bag & & $\begin{array}{l}\text { Rinse with distilled } \\
\text { Water }\end{array}$ \\
\hline
\end{tabular}

Table.2 Laboratory analysis method

\begin{tabular}{|l|l|l|}
\hline Parameter & Method & Method reference \\
\hline Total organic content (TOC) & Dichromate wet oxidation & USEPA 830 \\
\hline Electrical conductivity & HACH Meter & Conductivity meter \\
\hline $\mathrm{pH}$ & Electrode Absorption & APHA 4500 H \\
\hline $\begin{array}{l}\mathrm{Heavy} \mathrm{Metals:} \mathrm{Cd}, \mathrm{Cr}, \mathrm{Co}, \mathrm{Hg}, \mathrm{Pb}, \mathrm{Ni}, \mathrm{Zn} .\end{array}$ & $\begin{array}{l}\text { Atomic } \\
\text { Spectrometry }\end{array}$ & \\
\hline
\end{tabular}


Table.3 Results of pre-application and post application soil samples.

\begin{tabular}{|c|c|c|c|c|c|c|c|c|c|c|c|}
\hline & \multirow[t]{2}{*}{ PARAMETERS } & \multicolumn{4}{|c|}{ Pre-Application } & \multicolumn{4}{|c|}{ Post-Application } & \multicolumn{2}{|c|}{$\begin{array}{l}\text { DPR } \\
\text { Soil(mg/kg } \\
\text { drymateri } \\
\text { al) }\end{array}$} \\
\hline & & Point1 & Point2 & Point3 & Point4 & Point1 & Point2 & Point3 & Point4 & $\begin{array}{l}\text { Target } \\
\text { Value }\end{array}$ & $\begin{array}{l}\text { Intervention } \\
\text { Value }\end{array}$ \\
\hline & \multicolumn{5}{|l|}{ Physico-Chemical } & \multicolumn{4}{|c|}{ Physico-Chemical } & & \\
\hline 1 & $\mathrm{pH}$ & 5.7 & 5.2 & 5.1 & 5.8 & 6.1 & 5.7 & 5.7 & 6. & & \\
\hline 2 & $\begin{array}{l}\text { Electrica } \\
1 \\
\text { Conducti }\end{array}$ & 28.0 & 72.7 & 26.9 & 214.4 & 27.3 & 74.8 & 29.1 & 210.8 & & \\
\hline \multirow[t]{2}{*}{3} & TOC $(\%)$ & 0.98 & 1.30 & 0.92 & 2.10 & 0.73 & 0.99 & 0.87 & 1.90 & & \\
\hline & \multicolumn{5}{|l|}{ HeavyMetals } & \multicolumn{4}{|c|}{ HeavyMetals } & & \\
\hline 4 & Arsenic $(\mathrm{mg} / \mathrm{kg})$ & $<0.001$ & $<0.001$ & $<0.001$ & $<0.001$ & $<0.001$ & $<0.001$ & $<0.001$ & $<0.001$ & 29 & 55 \\
\hline 5 & Barium $(\mathrm{mg} / \mathrm{kg})$ & 0.65 & 1.09 & 0.50 & 1.18 & 0.60 & 1.13 & 0.67 & 1.23 & 200 & 625 \\
\hline 6 & Cadmium(mg/kg) & 0.573 & 0.382 & 0.763 & 0.954 & 0.490 & 0.321 & 0.793 & 0.271 & 0.8 & 12 \\
\hline 7 & Chromium $(\mathrm{mg} / \mathrm{kg})$ & 0.05 & 0.05 & $<0.001$ & 0.05 & $<0.001$ & 0.05 & 0.06 & 0.07 & 100 & 380 \\
\hline 8 & Cobalt(mg/kg) & 0.10 & 0.05 & 0.10 & 0.10 & 0.15 & 0.22 & 0.17 & 0.14 & 20 & 240 \\
\hline 9 & Copper $(\mathrm{mg} / \mathrm{kg})$ & 1.609 & 2.574 & 2.252 & 2.574 & 2.736 & 1.568 & 2.526 & 5.451 & 36 & 190 \\
\hline 10 & $\operatorname{Mercury}(\mathrm{mg} / \mathrm{kg})$ & $<0.001$ & $<0.001$ & $<0.001$ & $<0.001$ & $<0.001$ & $<0.001$ & $<0.001$ & $<0.001$ & 0.3 & 10 \\
\hline 11 & Lead(mg/kg) & 25.450 & 80.026 & 30.149 & 92.388 & 27.640 & 83.052 & 29.547 & 65.831 & 85 & 530 \\
\hline 12 & Nickel $(\mathrm{mg} / \mathrm{kg})$ & 1.524 & 3.049 & $<0.001$ & 1.524 & $<0.001$ & 3.708 & $<0.001$ & 2.769 & 35 & 210 \\
\hline 13 & Zinc(mg/kg) & 8.936 & 45.390 & 9.787 & 10.355 & 10.094 & 23.964 & 6.984 & 20.709 & 140 & 720 \\
\hline
\end{tabular}

Fig.1 Layout of the impacted soil showing the four segments

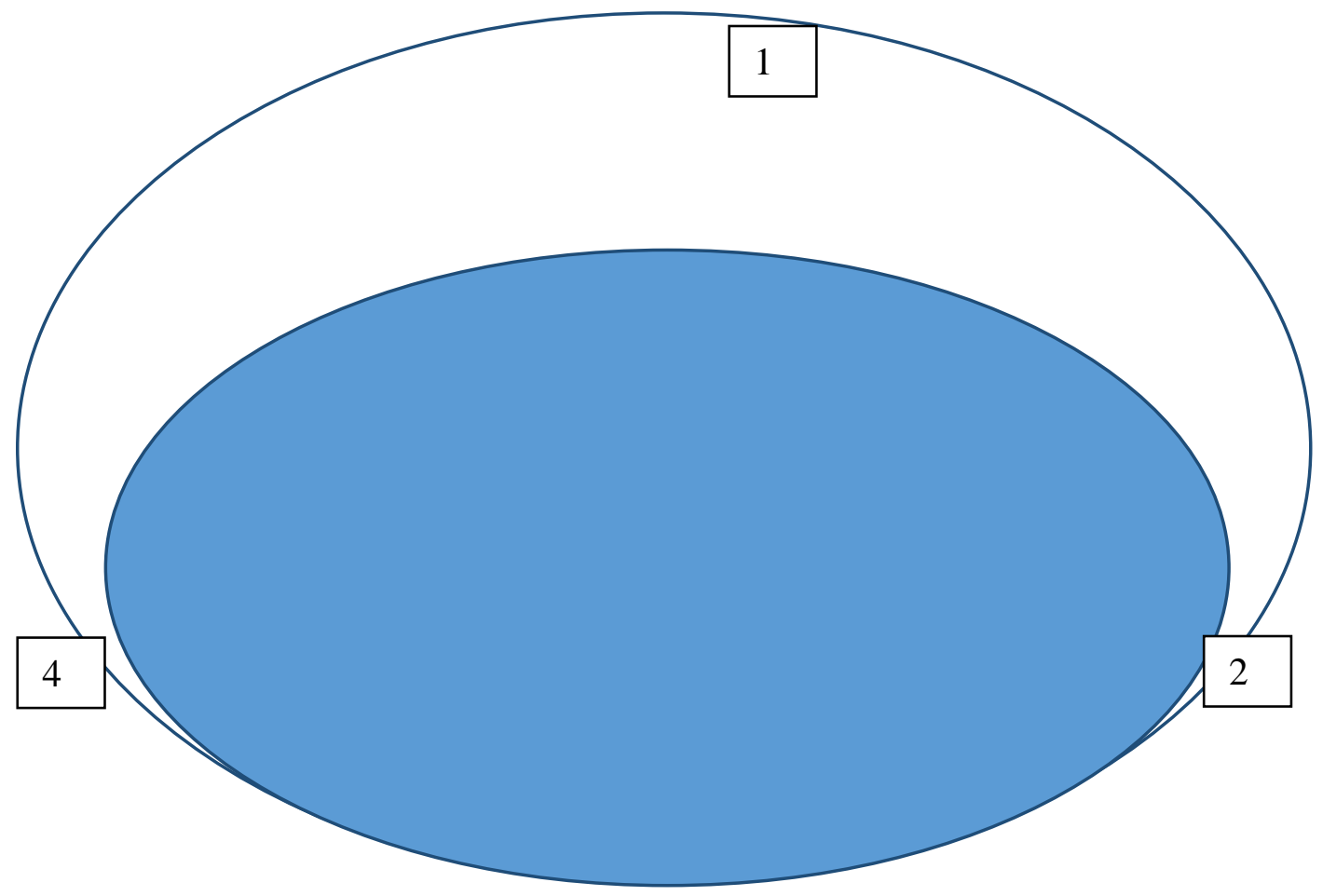


Fig.2 Change of impacted soil $\mathrm{pH}$ at the sample stations

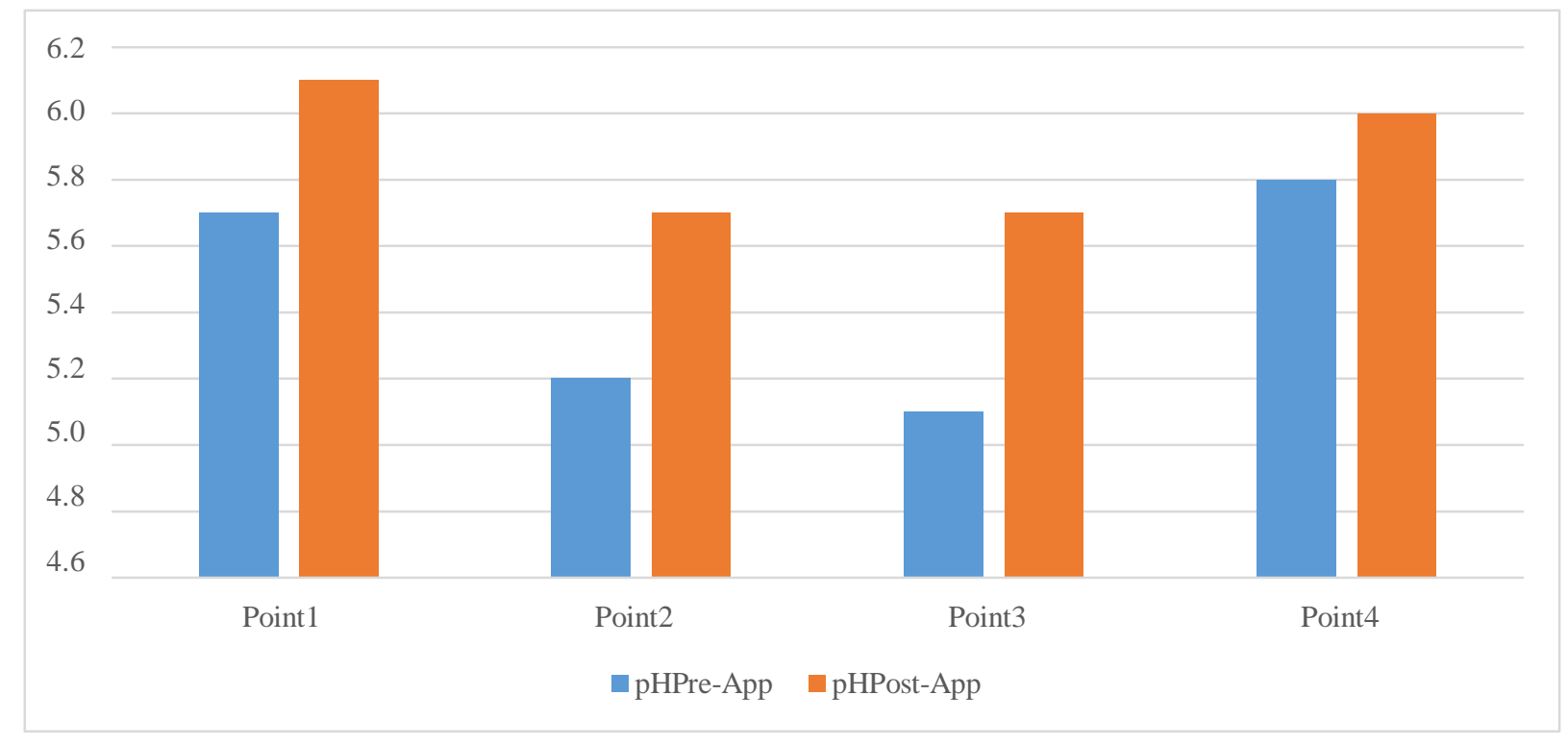

Fig.3 Change of Impacted Soil Electrical Conductivity at the sample stations

250

200

150

100

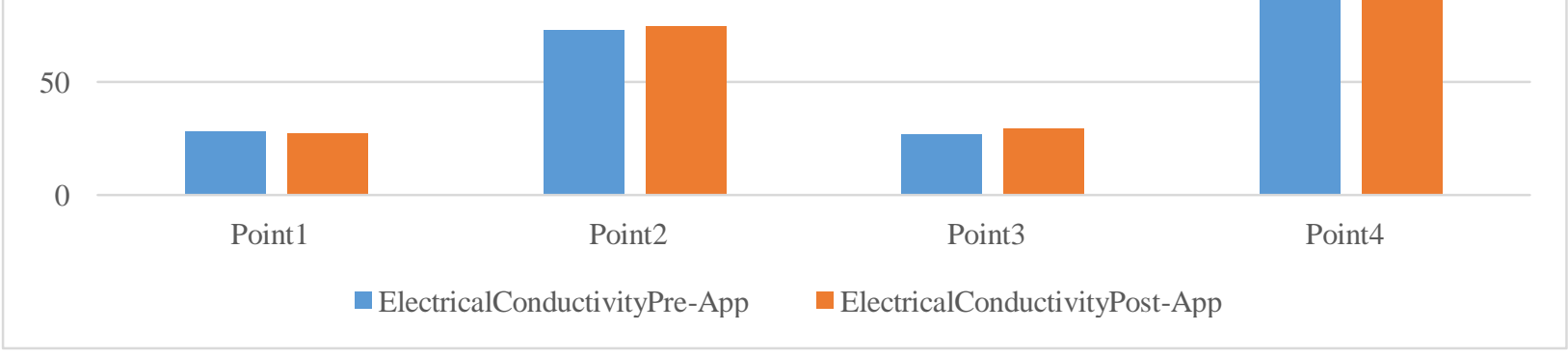


Fig.3 Change of Impacted Soil Total Hydrocarbon Content

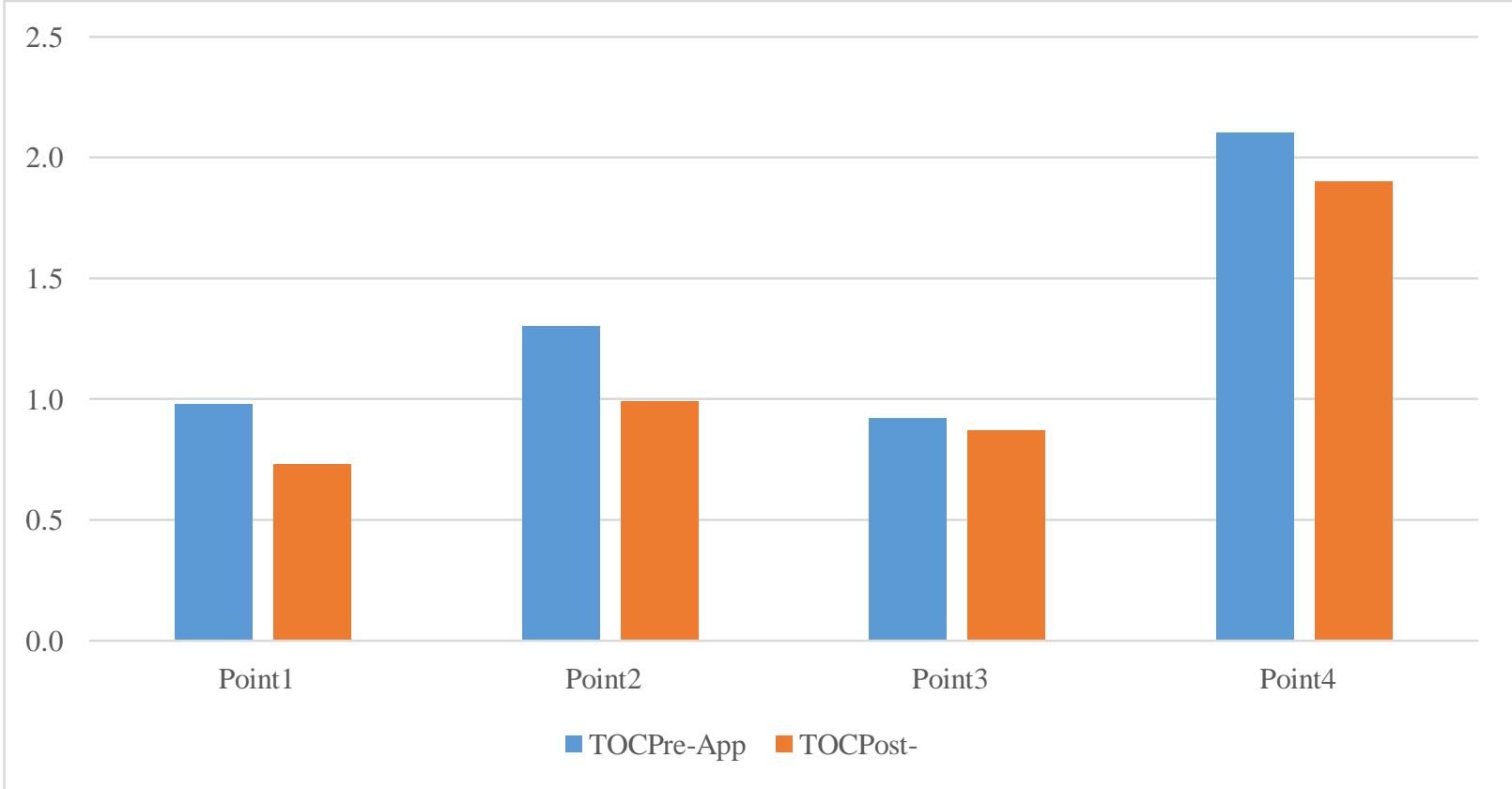

Fig.4 Change of Impacted Soil selected heavy metal content

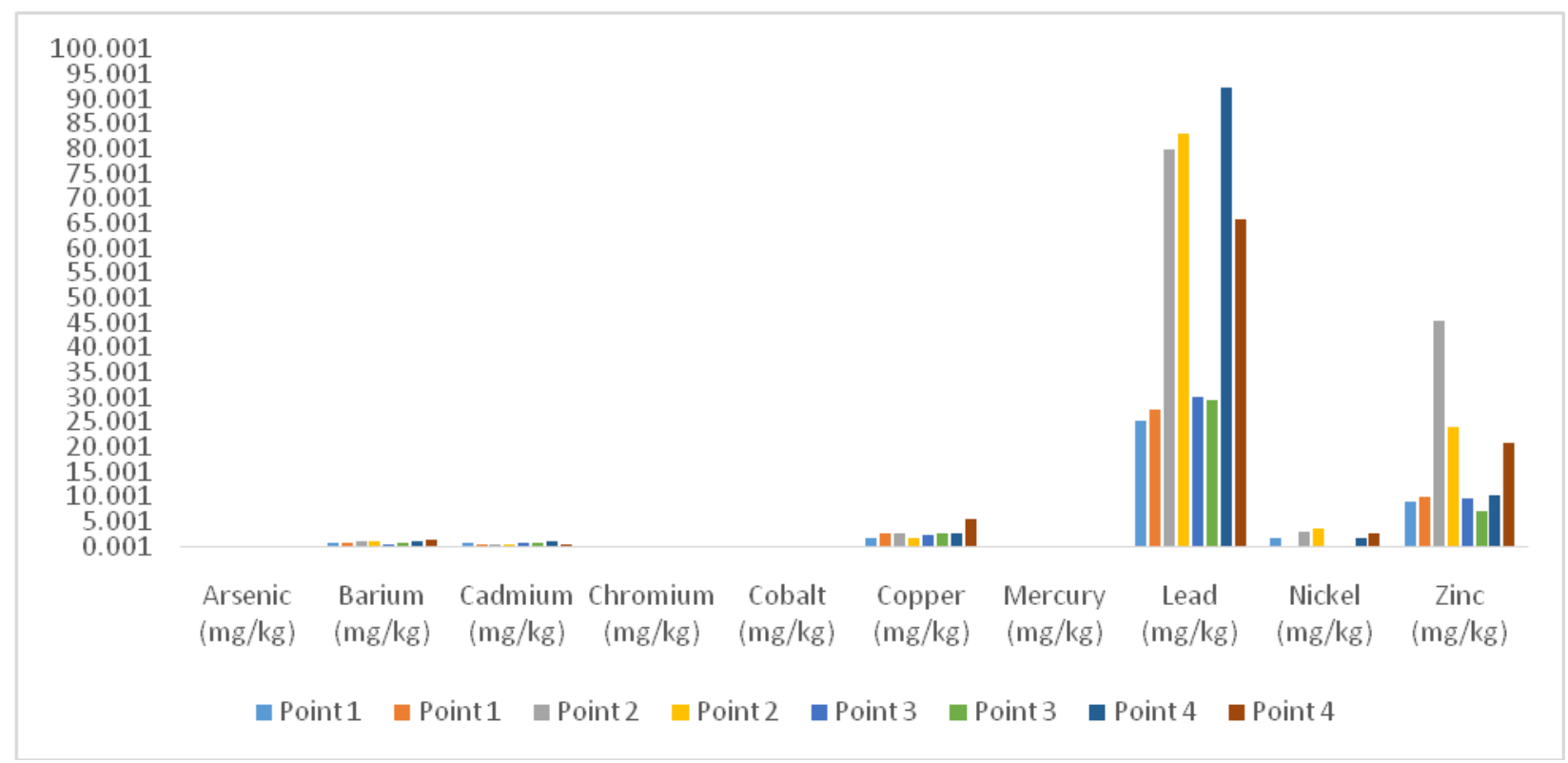

Arsenic and mercury have negligible concentrations in the pre and post application soil samples. Though, the concentration of the metals in the soil samples were lower than the limits, one would expect a visible reduction in the concentrations of these metals in the soil samples after application of the remedial agent, but this was not apparent in the results. The results are as shown in figure 2.4 . 
Another procedure could be to increase the number of lag days and then assess if there would be visible change in the concentration of these metal. Lack of materials have not made it possible for such procedure to be considered in this work.

The volume of impacted soil tested for remediation was approximately $38.68 \mathrm{~m}^{3}$.

Approximately 1 gallon of $10 \%$ live synergistic bacteria was used for the remediation experiment of 1 cubic yard $\left(0.765 \mathrm{~m}^{3}\right)$ of impacted soil. Based on the estimated volume of impacted soil, approximately 191.63 litres of the diluted solution was used on the site.

In conclusion, this work shows that impacted soil samples contain barium, cadmium, chromium, copper, lead, nickel and zinc at concentrations lower than the limits set by the department of petroleum resources. Lead recorded the highest concentration and chromium recorded the lowest concentration. It is also evident from the work that while the live synergistic bacteria could be effective in remediation at sites contaminated with organic compounds, its effectiveness against heavy metal is not visible within the period tested in this work. It is therefore recommended that further experiment should adjust the time lag between pre-application and post application analysis to really establish the potent of live synergistic bacteria in remediation actions at sites contaminated with heavy metals.

\section{References}

Alexander, M. 1999. Biodegradation and Bioremediation. Academic Press, SanDiego, USA, p.99.

ASTM. 1991. E 94391 Definitions of terms relating to biological effects and environmental fate. In: Annual
Book of ASTM Standards, Water and Environmental Technology. American Society for Testing and Materials Publication Vol.11.04, Philadelphia.

Blaylock, M.J., Huang, J.W. 2000. Phytoextraction of metals. In: I. Raskin and B.D. Ensley eds. Phytoremediation of toxic metals: using plants to clean-up the environment. New York, John Wiley and Sons, Inc., pp. 53-70.

Bragg, J.R., Prince, R.C., Harner, E.J., Atlas, R.M. 1994. Effectiveness of bioremediation for the Exxon Valdezoilspill. Nature, 368: 413418.

Duris, M. 2002. Geochemical and ecological survey of the Prague urban area. Geochim summer school, internal report.

Environmental Guidelines and Standards for the Petroleum Industry in Nigeria (EGASPIN). 2002. Department of Petroleum Resources. Accessed via https://dpr.gov.ng/index/egaspin on May 5th 2016.

Guo, G.L., Zhou, Q.X. 2006. Evaluation of heavy metal contamination in Phaeozem of Northeast China. Environ. Geochem. Health, 28: 33140.

Ke, W.S., Xi, H.A., Yang, Y., Wang, W.X., Chen, S.J. 2001. Analysis on characteristics of phytogeochemistry of Elsholtziahaichowensis in Daye Tonglushan copper mine. Acta Ecol. Sinica (In Chinese) 21: 907-912.

Mohammed Yazdi, NergesBehzad. 2009. Heavy metal contamination and distribution in the Parks city of Islam Shahr, Southwetern Tehran, Iran. The Open Environ. Pollu. Toxicol. J., 1: 49-53.

National Research Council (NRC). 1993. Principles of Bioremediation. In 
Situ Bioremediation: When Does it Work?. Washington, DC: The National Academies Press.doi:10.17226/2131.Accesss via http://www.nap.edu/read/2131/chap ter/1

National Population Commission Nigeria (NPC). 2006. National and State Population and Housing Tables 2006 Census Priority Tables Volume 1. Accessed viahttp://www.population.gov.ng/ind ex.phc on May 5th 2016.

Odukoya, A.M., Abimbola, A.F., Lawal, O. 2011. Potential soil contamination with toxic metals in the vicinity of active and abandoned dumpsites. Agri. Biol. J. North America, (5): 785-790.

Odukoya, A.M., Abimbola, A.F. 2010. Contamination assessment of surface and groundwater within and around two dumpsites. Int. J. Environ. Sci. Tech., 7(2): 367-376.

Oresanya, O. 2000. Method of landfill and landfill equipments. A technical paper on Workshop on the role of sanitary landfilling in integrated solid waste management. 60p.

Pandey, P.K., Sharma, R., Roy, M., Roy, S., Pandey, M. 2006. Arsenic contamination in the Kanker district of central-east India: geology and health. Environ. Geochem. Health, 28: 409-20.
Popoola, O.E, Bamgbose, O., Okonkwo, O.J., Arowolo, T.A., Odukoya, A.M., Popoola, A.O. 2012. Heavy Metals Content in Playground Topsoil of Some Public Primary Schools in Metropolitan Lagos, Nigeria. Res. J. Environ. Earth Sci., 4(4): 434-439.

Song, H.G., Wang, X., Bartha, R. 1990. Bioremediationpotentialofterrestrial fuel spills. Appl. Environ. Microbiol., 56: 652-656.

United State Environmental Protection Agency (USEPA). 2000. Accessed via https://www.epa.gov/waterdata/natio nal-water-quality-inventory-reportcongress on May 5th, 2016.

Vasiliadou, S., Dordas, C. 2009. Increased concentration of soil cadmium affects on plant growth, dry matter accumulation, $\mathrm{Cd}$, and $\mathrm{Zn}$ uptake of different Tobacco cultivars (Nicotia natabacum L). Int. J. Phytoremediation, 11: 115-130.

Venosa, A.D., Suidan, M.T., Wrenn, B.A., Strohmeier, K.L., Haines, J.R., Eberhart, B.L., King, D.W., Holder, E. 1996. Bioremediation of experimental oil spill on the shoreline of Delaware Bay. Environ. Sci. Technol., 30: 1764-1775.

Winfield, A. 2001. Environmental Chemistry. Cambridge University Press. p. 60.

\section{How to cite this article:}

Oyet, G.I., and Audu, P. 2016. Evaluation of the Effectiveness of Live Synergistic Bacteria as a Bioremediation agent for selected Heavy Metals in Soils in Apapa-Lagos. Int.J.Curr.Microbiol.App.Sci. 5(6): 413-421. doi: http://dx.doi.org/10.20546/ijcmas.2016.506.048 